\title{
HAM DAN BIROKRASI PERADILAN DI INDONESIA
}

\author{
Oleh : \\ Nur Yahya
}

Dalam kehidupan berbangsa dan bernegara, liberalisasi dan globalisasi membawa dampak yang sangat luas dan konkrit. Fenomena ini terlihat dengan munculnya ke permukaan panggung politik nasional di tingkat Majelis mengenai urgensi Deklarasi Pengakuan dan perlindungan Hak Asasi Manusia (HAM). Kuatnya pertentangan kelompok "universalisme" yang dipelopori oleh lembaga swadaya masyarakat dengan kelompok "partikularisme" yang didukung oleh aparat birokrasi, baik sipil maupun militer menandakan bahwa kemauan politik untuk merumuskan deklarasi HAM dalam produk MPR masih bersifat setengah hati. Kebenaran analisis ini akan semakin kuat apabila dikaitkan dengan perilaku birokrasi penegakan hukum yang berafiliasi di bawah pemerintah. Qua Vadis HAM!

\section{PENDAHULUAN}

Revolusi teknologi komunikasi merupakan salah satu faktor paling menentukan bagi percepatan liberalisasi dan globalisasi. Dalam konteks politik makro, globalisasi semakin mempertinggi tingkat korelasi dan interdependensi suatu negara terhadap negaranegara lain di dunia. Sebagai konsekwensinya hubungan antar pemerintah haruslah dijembatani dengan instrumen-instrumen internasional melalui cara penerimaan dan mengadopsi kesepakatan-kesepakatan/konvensikonvensi Internasional untuk selanjutnya ditempatkan sebagai bagian dari hukum nasional.

Dalam posisi ini instrumen-instrumen Internasional tentang HAM suka ataupun tidak suka akan memasuki altar kehidupan nasional kita. Yang menjadi permasalahan adalah bagaimana kesiapan sistem hukum nasional kita dalam mensikapi nilai-nilai HAM yang dibawa oleh arus globalisasi tersebut?

Secara kultural barangkali lebih mudah segera ditemukan faktanya bahwa ori-

Penulis adalah Dosen FH Univ. Wijaya Kusuma Surabaya entasi hukum nasional kita masih sangat domestik (Domestik Law Oriented). Dengan kata lain peradilan di Indonesia belum terbiasa menggunakan instrumen-instrumen dan atau konvensi-konvensi Internasional sebagai sumber hukum. Apalagi jika dikaitkan dengan HAM, Indonesia baru meratifikasi empat konvensi Internasional yaitu :

1. Convention on the Elimination of All Forms of Discrimintion against Woman.

2. Convention on the Political Rights of Woman.

3. Convention on the Rights of the Child dan,

4. International Convention Against Apartheid in Sports.

Oleh karenanya dibutuhkan suatu reorientasi dalam memandang nilai-nilai HAM pada situasi masyarakat global saat ini.

Reorientasi tersebut dipandang penting dan tidak dapat dielakkan mengingat terjadinya transisi sebagai akibat perubahan politik dunia setelah jatuhnya Blok Timur (Uni Soviet) dimana dihampir banyak belahan dunia terjadi situasi yang disebut sebagai transisi menuju demokrasi (LIPI 1997).

Nilai-nilai Demokrasi selalu menuntut adanya transparansi dalam segala hal, apalagi jika diingat Indonesia adalah negara hukum sehingga pengakuan dan perlindungan terhadap 